\title{
ANAESTHETIC DOSAGE FOR EPIDURAL SYMPATHETIC BLOCKADE
}

\author{
P. Y. Chen, M.D., AND Cloid D. Green, M.D. $†$
}

THE PURPOSE OF this study was to determine the minimal local anaesthetic dosage for blockade of the sympathetic nerves of the leg by the epidural route. Observations on the duration of the block were made when it occurred. The method of determining the presence or absence of sympathetic block was the psychogalvanic reflex (PGR).

\section{Methods and Material}

Twenty-seven subjects ranging in age from 19 to 76 years were studied. All were scheduled for operations on the lower portions of the body and all agreed to participate when the nature of the study was explained to them on the day before operation. They were in general healthy and received no pre-medication. The drug studied was lidocaine (Xylocaine) with epinephrine (1:200,000), four concentrations being used: 0.25 per cent, 0.375 per cent, 0.50 per cent, and 1.0 per cent. A volume of $10 \mathrm{ml}$ was injected in each instance. A catheter was placed in the epidural space through the second lumbar interspace using saline solution for identification of the space. ${ }^{1}$

The subject was placed supine and control PGR readings were obtained using the methods of Lewis ${ }^{2,3}$ and of Richter and Whelan. ${ }^{4}$ The test dose was then introduced into the epidural space. Observations of onset and duration of change in the $\mathrm{PGR}$ and in perception of temperature, pin prick, vibration, and touch, and of changes in motor function were then carried out. At the completion of the study, the anaesthesia necessary for the scheduled operation was obtained by injecting lidocaine of sufficient concentration. In all. cases the presence of the catheter in the epidural space was confirmed. Of the many methods of eliciting the PGR, cough and deep breathing were the most satisfactory stimuli for our purpose. The disappearance of the PGR is easily recognized immediately after establishment of the epidural block., ${ }^{2,3}$ The point which we considered to be recovery of the PGR was when the electrical signal had become as great as during the control period. The effect of absorption of local anaesthetic was studied by simultaneous observation of the PGR of the upper extremity and the lower extremity in eight patients. The effect of local anaesthetic absorption was further studied by observing the PGR in five subjects before and after the intramuscular injection of $10 \mathrm{ml}$ of 1 per cent lidocaine with epinephrine $(1: 200,000)$. One of these subjects received an additional $10 \mathrm{ml}$ of

†Dr. Chen is at New England Medical Center Hospital, Tufts University School of Medicine, 171 Harrison Avenue, Boston, Massachusetts 02111, U.S.A. Dr. Green is in the Department of Anesthesia, Faculty of Medicine, Memorial University of Newfoundland, St. John's, Newfoundland, Canada.

Can. Anaes. Soc. J, vol. 17, no. 6, November 1970 


\section{Sympathetic Block by Epidural}

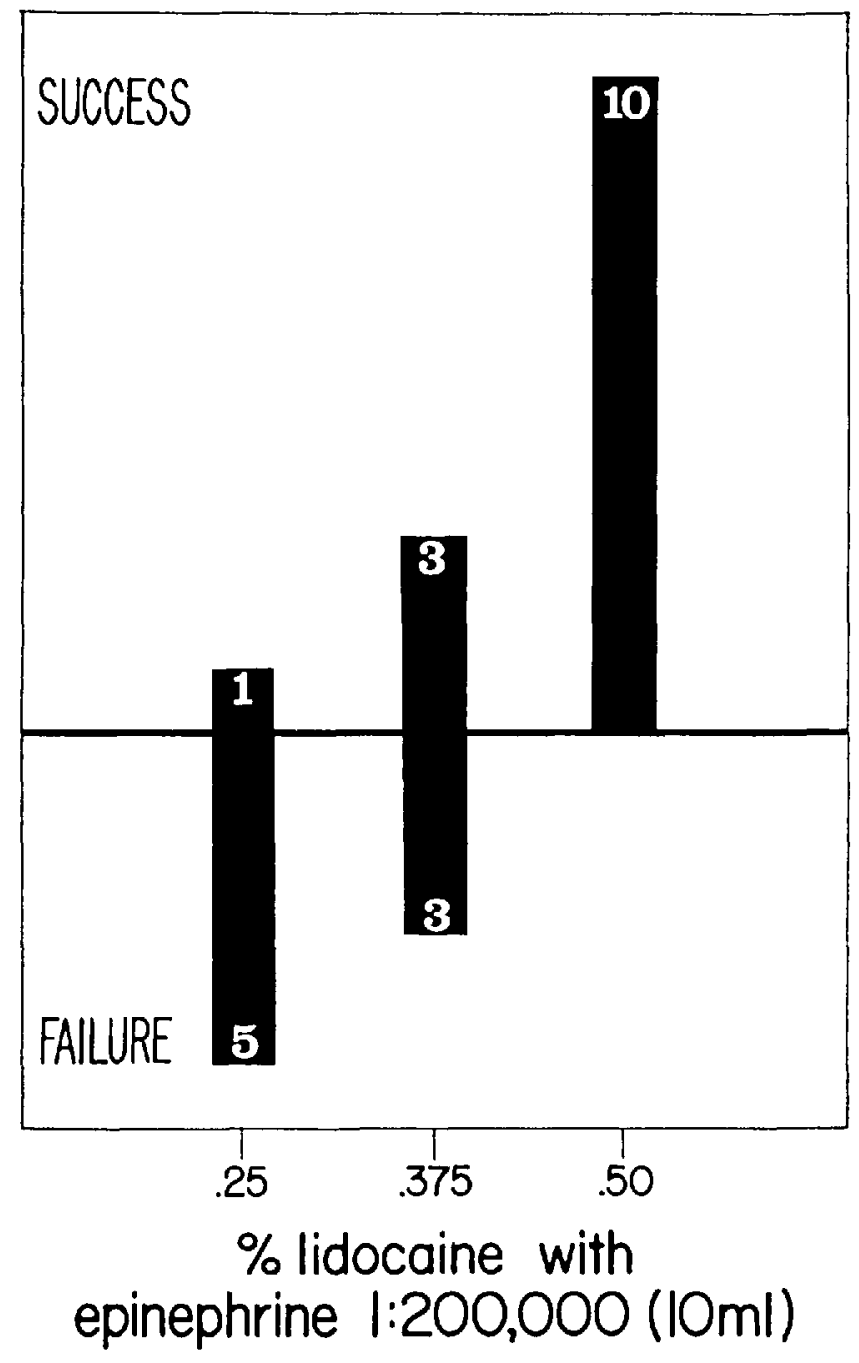

FIGURE 1. All subjects received $10 \mathrm{ml}$ of the test concentration of lidocaine with epinephrine 1:200,000 through a catheter in the epidural space. Lidocaine 0.375 per cent with epinephrine 1:200,000 represented the ED50. Lidocaine 0.5 per cent with epinephrine 1:200,000 produced sympathetic block in all subjects.

1 per cent lidocaine without epinephrine intravenously during a five-minute period.

\section{Results}

The effect of concentration on the occurrence of sympathetic block is shown in Figure 1. Of six subjects who received 0.25 per cent lidocaine with epinephrine, 
one developed block and five did not. Of ten subjects receiving 0.5 per cent lidocaine with epinephrine, all developed block. Of six receiving 0.375 per cent lidocaine with epinephrine, three developed block and three did not.

Comparison of the results of 0.5 per cent lidocaine with 0.375 per cent, by Fisher's Exact Probability Test, ${ }^{5,6}$ indicates that the probability of these results

\section{Duration of Sympathetic Block}

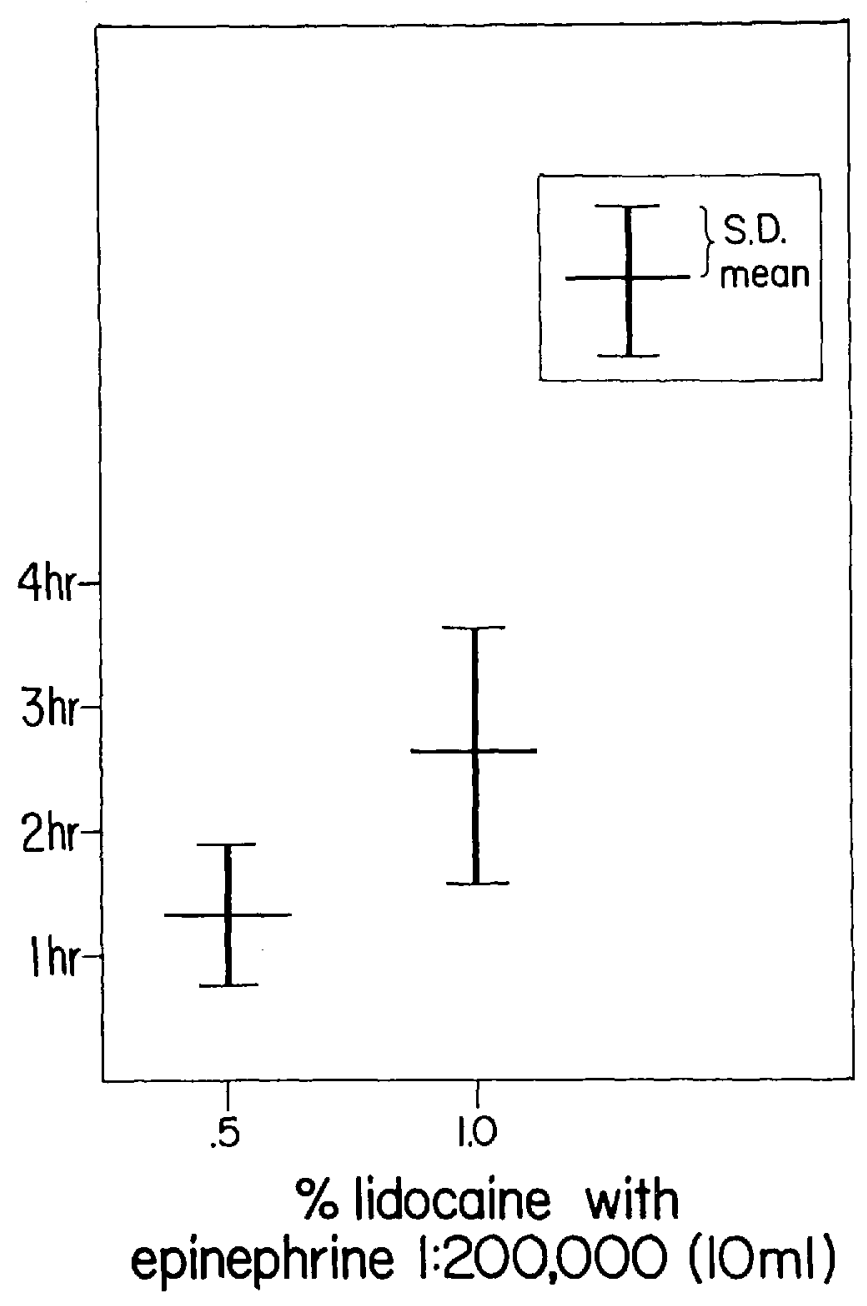

Ficune 2. The mean duration of sympathetic block produced by epidural administration of lidocaine 0.5 per cent with epinephrine 1:200,000 was 80 minutes, the standard deviation being 33 minutes. The mean duration of sympathetic block produced by the same method using lidocaine 1.0 per cent with epinephrine 1:200,000 was 156 minutes; the standard deviation was 62 minutes. 
occurring by chance is less than 5 per cent. Comparison of 0.5 per cent lidocaine with 0.25 per cent indicates that the possibility of the results occurring by chance is less than 0.5 per cent. From these analyses we can state with confidence that there is a significant difference between the effects of the three concentrations used and that the ED $50^{7}$ lies at, or close to, 0.375 per cent lidocaine with epinephrine $(1: 200,000)$.

The time of onset and duration of block produced by 0.5 per cent and 1 per cent solution is presented in Figure 2. With the 0.5 per cent concentration, onset of block ranged from 8 to 15 minutes, an average of 12.2 minutes. Duration ranged from 27 to 118 minutes with an average of 80 minutes (standard deviation, 33 minutes). There were sensory changes in only two subjects, who had subjective numbness. Pin-prick sensation persisted in all patients and no motor changes occurred. With the 1 per cent concentration, onset of block was markedly shortened, ranging from 3 to 5 minutes with an average of 4.25 minutes. Duration ranged from 85 to 256 minutes with an average of 156 minutes (standard deviation of duration, 62 minutes). Invariably, all subjects who received 1 per cent concentration had some degree of sensory and motor loss. Cryosensation was lost first, then sensation to pin prick - the sensory level ranging from the $\mathrm{T}-10$ to the $\mathrm{T}-4$ dermitome. All subjects had a slight but incomplete loss of touch and vibratory sense. Motor power was diminished but complete paralysis never occurred.

No subject had a significant change in blood pressure, which was measured by the conventional cuff and stethoscope over the brachial artery.

Of the eight subjects on whom simultaneous upper and lower extremity PGR was measured before and after the epidural injection of either 0.5 per cent or I per cent lidocaine, all developed lower extremity PCR block without change in the upper extremity PGR. The lower extremity PGR of the five subjects receiving intramuscular lidocaine 1 per cent with epinephrine $(1: 200,000)$ showed no alteration during 30 minutes following injection. The one subject who received intravenous 1 per cent lidocaine also showed no change in the lower extremity PGR.

\section{Discussion}

The rapid alteration of the electrical activity of the skin produced by stimulation of the sympathetic nervous system has been known as the "Tarchanoff phenomenon" since its original description. ${ }^{8}$ There is ample evidence to show that the $P G R$ is a response to an impulse from the intact sympathetic nervous system. ${ }^{0-13}$

Our selection of the volume of $10 \mathrm{ml}$ was based on our clinical experience and the recorded observations of others. Preliminary observations on several subjects to whom $5 \mathrm{ml}$ lidocaine, 0.5 per cent with epinephrine $(1: 200,000)$ was administered indicated the absence of block with this dose. Data obtained by Moore ${ }^{14}$ indicate that the epidural space will contain 1.5 to $2 \mathrm{ml}$ of solution per segment. We observed sensory blocks many segments higher than expected in several patients who received 1 per cent lidocaine. To be sure of obtaining adequate level in all patients, though, it was thought necessary to use the $10 \mathrm{ml}$ dose.

The median effective dose (ED50) of lidocaine with epinephrine to produce sympathetic block was found to be 0.375 per cent. A larger series might indi- 
cate a slightly higher or slightly lower concentration. This information, however, is of less value in a clinical situation than the determination of the concentration which will reliably produce sympathetic block in all cases.

Lidocaine 0.5 per cent with epinephrine $(1: 200,000)$ was successful in ten successive cases without interference with the majority of sensory tracts. The average duration of the block was 80 minutes. Lidocaine 1 per cent with epinephrine 1:200,000 produced block averaging 156 minutes, or approximately twice the duration, but also produced partial blocks of sensory and motor tracts. The choice between the two concentrations will depend upon whether sensory block would interfere with the purpose of the clinician and upon the duration of block desired.

Several advantages accrue to the use of the epidural route for lumbar sympathetic block. One of these is that the lumbar epidural route is technically easy and highly successful as compared with paravertebral block. A second is that as long as the catheter is in place the block can be renewed without difficulty to the physician or discomfort to the patient. A third advantage is that the epidural route blocks all lumbar sympathetic fibers, thus obviating the problem of aberrant pathways which have been proven to be residual following surgical sympathectomy ${ }^{15-19}$ and which may account for the occasional failure to obtain total sympathetic block by the paravertebral technique.

\section{Summary ANd Conclusions}

The anaesthetic dose for epidural sympathetic block was determined by the objective method of the PGR in a group of surgical patients. It was found that $10 \mathrm{ml}$ of 0.375 per cent lidocaine with epinephrine $(1: 200,000)$ was the median effective dose (ED50) in six patients; however, we concluded that $10 \mathrm{ml}$ of 0.5 per cent lidocaine with epinephrine was the minimal concentration which can be reliably used clinically to produce sympathetic block by the epidural route.

The onset and duration of sympathetic block produced by $10 \mathrm{ml}$ of lidocaine, 0.5 per cent and 1.0 per cent concentrations with epinephrine were also studied.

\section{RÉSUMÉ}

La dose efficace moyenne (ED50) de lidocaïne avec épinéphrine 1:200,000 pour produire un blocage sympathique des jambes par injection épidurale est $10 \mathrm{ml}$ d'une solution à $0.375 \%$. La lidocaïne $0.5 \%$ avec épinéphrine 1:200,000 a produit un blocage sympathique chez tous les sujets sans faire de blocage sensoriel ou moteur. La lidocaïne à 1.0\% avec épinéphrine 1:200,000 a procuré un blocage d'une durée presque double accompagné de degrés variables de blocage sensoriel et de faiblesse motrice.

\section{REFERENCES}

1. Bromage, P. R. Continuous Epidural Analgesia. In Spinal Epidural Analgesia (Baltimore: Williams \& Wilkins 1954).

2. LEwIS, L. W. Evaluation of Sympathetic Activity Using Standard Equipment. Surg. Forum Clin. Con. Am. College Surg. (1952). 
3. Lewis, L. W. Evaluation of Sympathetic Activity Following Chemical or Surgical Sympathectomy. Anesth. Analg. 34: 334 (1955).

4. Richter, C. P. \& Whelan, F. Sweat Gland Responses to Sympathetic Stimulation Studied by the Galvanic Skin Reflex Method. J. Neurophysiol. 6: 191 (1943).

5. Maxwell, A. E. Analysing Qualitative Data (New York: John Wiley \& Sons 1961).

6. Siegel, Sidney. Nonparametric Statistics for the Behavioral Sciences (New York: McGraw-Hill 1956).

7. Goodman, L. S. \& Gilman, A. G. The Pharmacological Basis of Therapeutics. 3rd ed. (New York: MacMillan 1965).

8. TarchanofF, J. Ueber die Galvanischen Erscheinunger in der Haut des Menschen bie Reigungen der Sinnersorgane und bei Verschiedeen Former der Psychischen Thatigkeit. Arch. f.d. ges. Physiol. 46: 46 (1890).

9. Richter, C. P. A Study of the Electrical Skin Resistance and the Psychogalvanic Reflex in a Case of Unilateral Sweating. Brain. 50:216 (1927).

10. Richter, C. P. Nervous Control of the Electrical Resistance of the Skin. John Hopkins Hosp. Bull. 45: 56 (1929).

11. Richter, C. P., \& Woodruff, B. G. Changes Produced Sympathectomy in the Electrical Resistance of the Skin. Surgery 10: 957 (1941).

12. Langworthy, O. R., \& Richter, C. P. The Influence of Efferent Cerebral Pathway upon the Sympathetic Nervous System. Brain. 53: 178 (1930).

13. Wanc, G. C. The Galvanic Skin Reflex. A Review of Old and Recent Works from a Physiologic Point of View. Am. J. Phys. Med. 36: 295 (1957) \& $37: 35$ (1958).

14. Moore, D. C.; Bridenbauch, L. D.; Van Ackeren, E. G; Belda, F. B.; \& Cole, F. V. Spread of Radiopaque Solutions in the Epidural Space of the Human Adult Corpse. Anesthesiology. 19: 377 (1958).

15. Skooc, T. Ganglia in the Communicating Rami of the Cervical Sympathetic Trunk. Lancet 2: 457 (1947).

16. Alexander, W. F.; Kuntz, A.; Henderson, W. P.; \& Ehrlich, E. Sympathetic Conduction Pathways Independent of Sympathetic Trunks: Their Surgical Implications. J. Intern. Coll. Surg. 12: 111 (1949).

17. Alexander, W. F.; Kuntz, A.; Henderson, W. P.; \& Erlich, E. Sympathetic Ganglion Cells in Ventral Nerve Roots; Their Relation to Sympathectomy. Science. 109: 484 (1949).

18. Kuntz, A., \& Alexander, W. F. Surgical Implications of Lower Thoracic and Lumbar Independent Sympathetic Pathways. Arch. Surg. 61: 1007 (1950).

19. Wiesman, G. G.; Jones, D. S.; \& Randald, W. C. Sympathetic Outllows from Cervical Spinal Cord in the Dog. Science. 152: 381 (1966). 